\title{
The German Federal Constitutional Court's Exercise of Ultra Vires Review and the Possibility to Open an Infringement Action for the Commission
}

\author{
Sara Poli ${ }^{\star}(1)$ and Roberto Cisotta ${ }^{* *}$
}

(Received 04 July 2020; accepted 08 July 2020)

\begin{abstract}
The paper examines the possible opening of an infringement procedure against Germany as a result of the breaches that emerge from the declaration by the German Constitutional Court that the Court of Justice has acted ultra vires in the Weiss judgment (C-493/17). The proportionality assessment of the Public Sector Purchase Programme (PSPP) of the European Central Bank (ECB), carried by the Court of Justice, is contested by the domestic court. We recall that the Commission enjoys great discretion regarding the launch of an infringement action based upon Article 258 of the TFEU and may be reluctant to use its powers, considering the special position of the constitutional courts in the context of Article 267 TFEU as well as the present situation of emergency following the pandemic. Yet, the possibility to start an infringement procedure for breaches of Treaty obligations resulting from an incorrect interpretation of domestic courts was admitted in case C-129/00 Commission v. Italy and applied in two subsequent cases (C-154/08 Commission v. Spain and C-416/17 Commission v. France). As a result of the ruling of May 5, 2020, the Court of Justice may find that Germany failed to fulfil obligations stemming from Article 267 TFEU and the related case-law, Article 19 TEU, as well as Article 5(2) TEU. Other breaches concern the independence of the ECB and of the Bundesbank (being it a Member of the European System of Central Banks (ESCB) and of the Eurosystem) as defined in Articles 130, 282(3) TFEU and Article 7 of the Protocol (No. 4) on the Statute of the ESCB and of the ECB. We argue in favour of the violation of all these provisions read in conjunction with the duty of loyal cooperation, laid down in Article 4(3) TEU. Yet, we conclude that it is uncertain whether the Commission will open (or continue) an infringement procedure against Germany since the Bundesbank may act to satisfy the requests of the German Constitutional Court in relation to the proportionality of the PSPP. It is to be hoped that the German State organs will make sure that the PSPP may be continued, thus ensuring the functioning of the Eurozone, despite the attack of the BVerfG to the EU Judicature and to Weiss ruling in particular.
\end{abstract}

Keywords: Principle of loyal cooperation; Infringement procedure; European Central Bank; German Constitutional Court and ultra vires review; Preliminary ruling procedure

*Sara Poli, Professor of EU law, University of Pisa.

${ }^{* *}$ Roberto Cisotta, Senior Lecturer in EU Law, University of Macerata; Diplomat, on special leave. The opinions expressed are strictly personal and do not engage the Italian Ministry of Foreign Affairs. The two authors jointly conceived the ideas behind the article and have drafted Sections A and E together. Sara Poli has drafted Sections B, C and D.I. Roberto Cisotta has drafted Sections D.II and D.III. This article reflects the state of developments of June 25, 2020.

(C) The Author(s), 2020. Published by Cambridge University Press on behalf of the German Law Journal. This is an Open Access article, distributed under the terms of the Creative Commons Attribution licence (http://creativecommons.org/licenses/by/4.0/), which permits unrestricted re-use, distribution, and reproduction in any medium, provided the original work is properly cited. 


\section{A. Introduction}

A few days after the ruling of the Bundesverfassungsgericht (BVerfG) of May 5, 2020, ${ }^{1}$ President von der Leyen issued a press release ${ }^{2}$ stating that the final word on EU law is always spoken in Luxembourg and nowhere else. The possibility of opening an infringement procedure was contemplated as a reaction to the ruling. This short essay is intended to explore a number of issues pertaining to the starting of an action, under Article 258 of the TFEU, by the Commission. ${ }^{3}$ First, we will emphasise the wide scope of the Commission's powers as to the opening of an infringement action and will consider the uncertainties surrounding the use of these powers against Germany (section B). The judgment of May 5, 2020 is historic since it is the first time that a Constitutional Court declared a pronouncement of the Court of Justice (CJEU), rendered in the context of a preliminary ruling procedure raised by the same BVerfG, as ultra vires. In light of this new development of EU law, we examine whether the legal conditions to start an infringement procedure are met (section C). In so doing, we focus on the criteria that were laid down by the CJEU in the case Commission v. Italy ${ }^{4}$ and on the practice. We examine the circumstances that led to a declaration by the judges of the Kirchberg that a Member State had failed to fulfil its Treaty obligations as a result of the interpretation by Courts of last instance in breach of EU law. We argue that, in principle, it is possible to open an action against Germany on the basis of Article 258 TFEU. Yet, since the ruling of the BVerfG, declaring that the Weiss judgment ${ }^{5}$ is $u l t r a$ vires, does not have immediate effects, any infringement action against Germany would be devoid of any purpose ${ }^{6}$ if at the expiry of the transitional period (three months) given by the BVerfG to the Bundesbank to coordinate with the European System of Central Banks, the German central bank was able to confirm that the PSPP complies with the proportionality principle. ${ }^{7}$ It is also possible that the German government or the Bundestag will take action in order to neutralise the consequences of the breach of EU law that can be identified in the judgment of May 5, 2020. In these circumstances, it might be inappropriate for the Commission to start an action after the expiry of the transitional period. ${ }^{8}$ Third, we dwell on the Treaty articles and principles

\footnotetext{
${ }^{1}$ BundesVerfassungsGericht [BVerfG] [Federal Constitutional Court], Joined Cases 2 BvR 859, 1651, 2006, \& 980/15 (May 5, 2020) [hereinafter Judgment of May 5, 2020].

${ }^{2}$ Ursula von Der Leyen, President, Eur. Comm'n, Statement (May 10, 2020), https://ec.europa.eu/commission/presscorner/ detail/en/statement_20_846.

${ }^{3}$ For first comments on a possible infringement action, see Daniel Sarmiento, An Infringement Action against Germany after its Constitutional Court's ruling in Weiss? The Long Term and the Short Term, EU LAW Live, https://eulawlive.com/ op-ed-an-infringement-action-against-germany-after-its-constitutional-courts-ruling-in-weiss-the-long-term-and-the-shortterm-by-daniel-sarmiento/(12 May 2020).

${ }^{4}$ Case C-129/00, Comm'n v. Italy, 2003 E.C.R. I-14637; Giacomo Di Federico \& Lucia Serena Rossi, Commentary, Commission v. Italy, 42 Common MKT. L. REv. 829 (2005).

${ }^{5}$ ECJ, Case C-493/17 Heinrich Weiss and Others, ECLI:EU:C:2018:1000 (Dec. 11, 2017), http://curia.europa.eu/juris/liste. jsf?language $=$ en $\&$ num $=\mathrm{C}-493 / 17$ [hereinafter Weiss Judgment].

${ }^{6}$ On the breaches resulting per se from the position taken by the BVerfG in its judgment of May 5, 2020, see section D.

${ }^{7}$ According to the BVerfG, the Bundesbank should make sure that the ECB Governing Council adopts a new decision that demonstrates in a comprehensible and substantiated manner that the monetary policy objectives pursued by the ECB are not disproportionate to the economic and fiscal policy effects resulting from the programme. See Judgment of May 5, 2020 at para 235. It has been suggested that the Bundesbank could ask the governing Council to better justify in terms of proportionality the Public Sector Purchase Programme ("PSPP"). It is possible that such an initiative could be sufficient to comply with the Court's ruling and to avoid an infringement procedure. Miguel Maduro, Speech, "After the ECB Judgement of the German Constitutional Court: Is EU Community Law in Jeopardy?" (June 18, 2018). On the forthcoming initiatives of the Bundesbank, see infra, Section E.

${ }^{8}$ The Commission enjoys a great freedom in deciding when an infringement action should be opened. In case the Commission decided to send a letter of formal notice to Germany before the expiry of the transitional period, the procedure under Article 258 TFEU could still be closed during its pre-trial stage, if the Commission considered that there is no EU interest to bring the case before the Court of Justice. This may happen as a result of the informal discussion held by the Commission with the German government. The latter should assure that the Weiss judgment will be respected.
} 
deriving from the case-law which were breached by the German Federal Court (section D). Finally, we draw some conclusions (section E).

\section{B. The Decision to Open an Infringement Procedure for Breaches of EU Obligations Attributable to Constitutional Courts: The Wide Scope of the Commission's Discretion}

The Commission has never launched an infringement procedure against a Member State for failure of its Constitutional Court to respect the Treaty obligations. Certainly, it is not a decision that can be taken lightly. Indeed, it is politically sensitive to start an action that may lead to a declaration that a Member State has failed to fulfil its obligations as a result of a ruling issued by its Constitutional Court. If the latter finds that one of the EU institutions, in particular the Court of Justice, has acted beyond the powers conferred on it by primary law, the Commission may find it politically difficult to put the German government between the anvil and the hammer: Either it disobeys its Constitutional Court or the Court of Justice. The difficulties lie first of all in the facts that the Karlsruhe court ensures respect of the Constitution and the transfers of powers by Germany to the EU have constitutional foundations; in addition, the act of disobedience by the BVerfG concerns the outer limits of EU law. The opening of an infringement procedure could provoke an escalation of the conflict, which in this very moment of the European Integration process, would not be in the interest of both the EU and Member States. ${ }^{9}$

In the recent practice, the Commission was faced with the dilemma of opening an infringement procedure against the Czech Republic and Denmark in circumstances which were broadly similar (though not identical) to those present in Germany. In 2012, the Czech Constitutional Court considered the Landtová ruling of the Court of Justice ${ }^{10}$ ultra vires for domestic reasons ${ }^{11}$ more than for a genuine distrust towards the judges of the Kirchberg. In 2016 the Danish Supreme Court ${ }^{12}$ raised a preliminary ruling on the interpretation of the general principles on the grounds of age in the case Ajos. ${ }^{13}$ Yet, as in the Czech case, it did not follow the judicial pronouncement of the Court of Justice. ${ }^{14}$ Despite these breaches, in neither of these cases the Commission decided to act against the two Member States. It is unfortunate that no explanations were provided on the reasons leading to this choice. Scholars seem to have minimized the salience of the domestic

\footnotetext{
${ }^{9}$ At the end of May, ground-breaking proposals were put forward to address the economic crisis due to the pandemic. The most important innovation is that the Commission will issue bonds on the financial markets on behalf of the EU to finance the EU recovery fund. The use of these powers is conceived of as a temporary exception from Article 311 TFEU, which does not allow the EU to borrow to finance its expenditures. In addition, the ceiling of the EU's own resources will be raised. This initiative was favoured by a Franco-German plan made known on May 18. See The EU Budget Powering the Recovery Plan for Europe, European Commission (COM 2020) 442 (2020), Financing the Recovery Plan fOr Europe (2020), https://ec.europa.eu/info/sites/info/files/about_the_european_commission/eu_budget/factsheet_3_v22.pdf; Ursula von der Leyen, President, European Commission, Statement (May 18, 2020); Press Release, Bundesregierung, A French-German Initiative for the European Recovery from the Coronavirus Crisis (May 18, 2020), https://www.bundesregierung.de/ resource/blob/973812/1753772/414a4b5a1ca91d4f7146eeb2b39ee72b/2020-05-18-deutsch-franzoesischer-erklaerung-engdata.pdf?download $=1$.

${ }^{10}$ ECJ, Case C-399/09, Marie Landtová, 2011 E.C.R I-0557 See Pl. ÚS 5/12, Slovak Pensions, Czech Constitutional Court case of 31 January 2012 [hereinafter Slovak Pensions]. For comments, see Jan Komárek, Playing with Matches: The Czech Constitutional Court's Ultra Vires Revolution, Verfassungsblog (Feb. 22, 2012), https://verfassungsblog.de/playingmatches-czech-constitutional-courts-ultra-vires-revolution/.

${ }^{11}$ The preliminary ruling was made by a rival court which had offended the Czech Constitutional Court. See Takis Tridimas, The ECJ and the National Courts, in OxFord HANDBOOK OF European LAW 421 (Damian Chalmers \& Anthony Arnull eds., 2015).

${ }^{12}$ This is not a constitutional court since Denmark does not have such a Court.

${ }^{13}$ ECJ, Case C-441/14, Dansk Industri (on behalf of Ajos A/S) v. Estate of Karsten Eigil Rasmussen [GC] (Den), (April 19, 2016), http://curia.europa.eu/juris/document/document.jsf?text=\&docid=176461\&pageIndex $=0 \&$ doclang $=i t \& m o d e=l s t \&$ $\operatorname{dir}=\& o c c=$ first $\&$ part $=1 \& \mathrm{cid}=7061153$.

${ }^{14}$ Case No. 15/2014 Dansk Industri (DI) acting for Ajos A/S vs. The estate left by A, www.hoejesteret.dk/hoejesteret/ nyheder/Afgorelser/Documents/15-2014.pdf.
} 
pronouncements. ${ }^{15}$ In light of these precedents, the Commission may decide to abstain from opening an infringement procedure. The consideration could be made that the BVerfG has found a way to interact in the context of the preliminary ruling procedure with the Court of Justice, after a longstanding reluctance to refer to the judges of the Kirchberg, shared by other Constitutional Courts, including the Italian Corte Costituzionale. The opening of an infringement procedure against Germany for the exercise of the ultra vires doctrine vis-a-vis the Court of Justice could be considered a sort of interference by the Commission in the delicate relations between the Constitutional Courts and the CJEU and may also lead to an increase in the tension between the Courts.

Yet, the scope of the Commission's discretion is wide in the context of an action under Article 258 TFEU: this institution could also take the view that it is in the EU interest to start an infringement procedure against Germany, taking into account the breaches of EU law attributable to this Member State. The fact that no actions were initiated with respect to Denmark and the Czech Republic is not a legal obstacle to open infringement proceedings in the case at hand; indeed, the Court of Justice has recognised a great degree of freedom to the Commission as to the target of its infringement actions. ${ }^{16}$

\section{The Opening of an Infringement Procedure for Interpretations of the Domestic Courts: the Controversial Precedential Value of Commission v. Italy and the Subsequent Practice}

On the basis of established case-law of the CJEU and also of international law, it is the state in its unity that is responsible for breaches of Treaty obligations committed by any of its state organs, including domestic courts. In addition, a Member State may not plead provisions (including those of constitutional nature), practices or circumstances, existing in the internal legal system to justify a failure to comply with the Treaty obligations. It should be stressed that in the past, there has been reluctance to use the enforcement procedure against a Member State for errors committed by courts of last instance. As it was stated by an author, "it has come about that application of a Treaty procedure [i.e. the infringement proceedings] which could have been reasonably shaped by the ECJ as far as infringements of national courts are concerned has been rather artificially limited by the Commission." 17

The possibility of opening infringement procedures for breaches imputable to the judiciary was admitted for the first time in Commission v. Italy. ${ }^{18}$ It is noteworthy that the case concerns both a failure to comply with the EU law by the legislature and an incorrect interpretation of Union law by domestic courts, including a court of last instance (the Supreme Court of Cassation). ${ }^{19}$ More precisely, in this ruling the Court of Justice pointed out that a Member State could be held responsible if they wrongly applied EU law, as a result of domestic legislation and of the interpretation provided by national courts. ${ }^{20}$ This may happen under restrictive conditions. The Court stresses that "isolated or numerically insignificant judicial decisions in the context of case-law taking a different direction, or still more a construction disowned by the national supreme court, cannot

\footnotetext{
${ }^{15} \mathrm{~A}$ scholar states that the Czech case "did not raise strategic issues for European integration." Takis Tridimas, supra note 11 , at 421 .

${ }^{16}$ Due to space constraints, we omit references to the case law on infringement actions. For a thorough analysis of this remedy see Luca Prete, Enforcement Actions, in OXford Principles of European LAW, vol. I 942 (Robert Schütze \& Takis Tridimas eds., 2018).

${ }^{17}$ Maciej Tabarowski, Infringement Proceedings and Non-Compliant National Courts, 49 CoMmON MKT. L. REV. 1881,1911 (2012).

${ }^{18}$ Comm'n v. Italy, Case C-129/00.

${ }^{19}$ The ruling does not concern the constitutional court.

${ }^{20}$ Robert Schütze, European Union LaW 382 (2d ed., 2018).
} 
be taken into account." ${ }^{21}$ Therefore, a single judicial decision does not seem to be enough to find that a Member State failed to comply with its Treaty obligations. Then, the Court went on to identify an exception: "That is not true of a widely-held judicial construction which has not been disowned by the supreme court, but rather confirmed by it." 22

In the concerned case, both lower courts and a court of last instance, the Italian Supreme Court of Cassation, had actually interpreted the law in a manner which was incompatible with EU obligations. In order to assess whether the Commission could open an infringement procedure against Germany the precedential value of this ruling is not straightforward. On the one hand, it is not clear whether the declaration of a judgment of the Court of Justice as ultra vires could qualify as a "widely held judicial construction." This is uncertain since in the context of the judicial pronouncement in Commission v. Italy this expression refers to an interpretation of the law which is adopted in a high number of judgments. ${ }^{23}$ On the other hand, there are good systemic reasons to consider that constitutional courts are subject to Treaty rules as any other court of last instance, despite the fact that the former courts often regard themselves as different from the latter for the purpose of the preliminary ruling procedure. Considering the crucial role that judges, against whose decisions there is no judicial remedy under national law, perform for the correct and uniform interpretation and application of EU law, it is of fundamental importance that constitutional courts respect the principle of supremacy. It is all the more important that they also accept that the final word on the validity of an EU act such as the decision establishing the PSPP is that of the Court of Justice which, unlike constitutional courts, is fully equipped to make such an assessment. ${ }^{24}$ Since it is the first time that the BVerfG challenges the tenets of the preliminary ruling procedure and questions the Court of Justice's respect of the principle of conferral, there is little doubt that the BVerfG breached Article 267 TFEU. $^{25}$

It is now necessary to examine when the ruling Commission v. Italy was applied in practice and see in what circumstances the Commission successfully took action against judicial decisions of Courts of last instance. In recent practice, it is possible to identify a couple of cases in which actions under Article 258 TFEU were upheld by the Court of Justice against two Member States for the incorrect interpretation of EU law by their Courts of last instance. This has happened in Commission v. Spain ${ }^{26}$ and in Commission v. France. ${ }^{27}$ In the former case the Tribunal supremo erroneously interpreted EU law without referring to the Court of Justice; ${ }^{28}$ yet, the Commission

\footnotetext{
${ }^{21}$ Comm'n v. Italy, Case C-129/00 at para 32.

${ }^{22} I d$.

${ }^{23}$ It should be noted that in the French translation of the concerned judgment the expression "widely-held construction" is translated from "une interprétation jurisprudentielle significative," which is very similar to the Italian version ("un'interpretazione giurisprudenziale significativa"). In the two mentioned linguistic versions, this notion could be interpreted as referring to a highly salient judicial pronouncement and therefore it could be used by the Commission to open an infringement action against Germany for the judgment of its constitutional court.

${ }^{24}$ ECJ, Case C-461/03, Gaston Schul Douane-expediteur BV, 2005 E.C.R. I-10513, para 24. It should be kept in mind that CJEU benefits from the possibility to hear parties, intervening Member States and EU Institutions, the Advocate General and thus its adjudication can take into account a wider set of points of view and interests. This is also why, in exercising its monopoly over the interpretation of EU Law, it enjoys a privileged position compared to that of national courts, as it is able to thoroughly weigh all factors that affect or confirm the validity of an EU act, such as the PSPP.

${ }^{25}$ For an author who has supported the view that Germany could face infringement proceedings if the Federal German Court openly disregarded a CJEU ruling, see Franz C. Meyer, Rebels Without a Cause? A Critical Analysis of the German Constitutional Court's OMT Reference, 15 GERMAn L.J. 111, 123-124 (2014).

${ }^{26}$ ECJ, Case C-154/08, Comm'n of the Eur. Comm. v. Kingdom of Spain, ECLI:EU:C:2009:695 (Nov. 12, 2009), 338, http:// curia.europa.eu/juris/document/document.jsf? text $=\&$ docid $=78257 \&$ pageIndex $=0 \&$ doclang $=$ FR\&mode $=1$ st $\&$ dir $=\& o c c=$ first $\&$ part $=1 \&$ cid $=582$.

${ }^{27}$ ECJ, Case C-416/17 Eur. Comm'n v. French Republic, ECLI:EU:C:2018:811 (Oct. 4, 2018), https://eur-lex.europa.eu/legalcontent/EN/TXT/HTML/?uri=CELEX:62017CJ0416\&qid=1592487945274\&from=EN.

${ }^{28}$ In this case, the failure to comply with EU obligations was attributed to Spain as a result of the breaches of the sixth VAT Directive as interpreted by the Tribunal supremo. By contrast, the breaches that can be found in the judgment of May 5, 2020 are entirely due to the judicial interpretation offered by the Federal Court of the Weiss judgment issued by the Court of Justice.
} 
based its infringement procedure only on the failure of the domestic court to correctly construe secondary law; the Court upheld the action. In the latter case, the Conseil d'Etat wrongly interpreted Articles 49 and 63 of the TFEU and a preliminary ruling of the Court of Justice. ${ }^{29}$ Yet, in contrast with the infringement action against Spain, the Commission complained that France had breached its obligations under Article 267(3) TFEU since its Court of last instance chose to depart from the interpretation provided by a ruling of the Court of Justice, without referring to the judges of the Kirchberg. ${ }^{30}$

The judgment of May 5, 2020 is different from both the Spanish and French rulings. In contrast with the former case, the Karlsruhe court has complied with its duty to refer, under Article 267(3) TFEU, as the Conseil d'Etat did. It should be noted that the position of the BVerfG is nevertheless different from the latter since it has rejected altogether the answers provided by the Court of Justice in the context of a preliminary ruling on the validity of EU acts and has declared the Weiss ruling ultra vires. This is one of the most serious breaches that a constitutional court could make and certainly the effects of the judgement are more disruptive for the preliminary ruling system than those associated with the other two cases. We will come back to this issue in the next section.

\section{The Envisaged Breaches of Treaty Obligations Committed by the BVerfG}

\section{Article 267 TFEU, the Related Principles of the Case-Law and Article 19(1) TEU}

Although the BVerfG had referred to the CJEU before activating its ultra vires doctrine, as it had committed to do in Honeywell, ${ }^{31}$ there are no doubts that the judgment of May 5, 2020, stands in itself in contradiction with several provisions of the Treaties. Indeed, by considering inapplicable a ruling of the Court of Justice on the validity of EU secondary law, the domestic court breached established principles of the case-law related to Article 267 TFEU. The judgment issued in the context of the preliminary ruling is binding ${ }^{32}$ both for lower courts, ${ }^{33}$ as well as courts against whose decisions there are no remedies under national law. "The mere fact of consenting to the jurisdiction of the CJEU creates an expectation of obedience" 34 which can be explained by the need to ensure that EU law is applied and interpreted in a uniform manner throughout the EU. As it was stated in opinion 2/2013: "[...] The judicial system [...] has as its keystone the preliminary ruling procedure provided for in Article 267 TFEU, which, by setting up a dialogue between one court and another, specifically between the Court of Justice and the courts and tribunals of the Member States, has the object of securing uniform interpretation of EU lawthereby serving to ensure its consistency, its full effect and its autonomy as well as, ultimately, the particular nature of the law established by the Treaties-."35

A further provision which is violated is Article 19(1) TEU. The second sentence of this Treaty article states that the Court of Justice of the EU shall ensure that in the interpretation and application of the Treaties the law is observed. The judgment of May 5, 2020 does not confine itself to

\footnotetext{
${ }^{29}$ ECJ, Case C-35/11, Test Claimants in the FII Group Litigation v. Commissioners of Inland Rev., ECLI:EU:C:2012:707 (Nov. 13, 2012), https://eur-lex.europa.eu/legal-content/EN/TXT/HTML/?uri=CELEX:62011CJ0035\&from=EN.

${ }^{30}$ Comm'n v. France, Case C-416/17 at paras 111-112.

${ }^{31}$ Bundesverfassungsgericht [BVerfG] [Federal Constitutional Court], 126 ENTSCHEIDUNGEN DES BUNDESVERFASSUNGSGERICHTS [BVERFGE] 286, para 60 (2010).

${ }^{32}$ ECJ, Case 69/85, Wünsche, 1986 E.C.R. 948, para. 13.

${ }^{33}$ ECJ, Case 314/85, Foto-Frost, 1987 E.C.R. 4199.

${ }^{34}$ Jan Komárek, The Place of Constitutional Courts in the EU, 9 EUR. CONST. L. REv. 420, 433 (2013).

${ }^{35}$ ECJ, Opinion 2/13, ECLI:EU:C:2014:2454 (Dec. 18, 2014), para. 176, http://curia.europa.eu/juris/document/document.jsf; jsessionid=236A8AEE9C93D7BFE00B27049BD9A4A5? text $=\&$ docid $=160882 \&$ pageIndex $=0 \&$ doclang $=$ EN $\& \mathrm{mode}=1 \mathrm{st} \&$ $\operatorname{dir}=\& o c c=$ first\&part $=1 \& \operatorname{cid}=6311583$.
} 
erroneously interpret EU law as courts of last instance did in the infringement procedures against Italy, Spain and France, but went beyond by refusing to consider the answers of the Court of Justice in the Weiss judgement as binding, thus preventing the CJEU from exercising its competence.

\section{The Provisions Granting Independence to the ESCB and the ECB}

It is submitted that the ruling which is here commented also affects the independence of the ECB and of the European System of Central Banks (ESCB), including the German Bundesbank.

It should be noted that the BVerfG has acted with the intention to protect the independence of the ECB and of the ESCB, as guaranteed by Articles 130 TFEU, 282(3) TFEU and Article 7 of the Statute of the European Central Bank and of the European System of Central Banks. ${ }^{36}$ In the opinion of the German constitutional judges, the independence of the monetary authorities could be jeopardised by the possibility to carry out a programme like the PSPP, whose economic policy effects have not been properly scrutinized by the CJEU. As the EU enjoys exclusive competence in the field of the monetary policy with respect the members of the Euro Area (Article 3(1)(c) TFEU), the alleged encroachment by the ECB upon the competence of the Member States in the area of economic policy ${ }^{37}$ may result in the exposure of the monetary authorities to political pressure. $^{38}$ The BVerfG asserts that by broadly interpreting ECB's mandate in the Weiss judgment, the CJEU has not only breached the principle of conferral but also jeopardised the independence of the ESCB and of the ECB. ${ }^{39}$

For the German judges, the request made to the Bundesbank to ask the ECB that it better justifies the proportionality of the PSPP neither affects the independence of the national central bank, nor that of the ECB. ${ }^{40}$ On the contrary, the ruling of judgment of May 5, 2020 should have the effect of reinforcing the independence of European monetary authorities.

The reasoning of the Court sitting in Karlsruhe can be criticised for two reasons: first, the economic analysis made by the BVerfG to prove that the economic effects of the PSPP exceeded the ECB's mandate is questionable, as experts in this field pointed out. ${ }^{41}$ Second, drawing the dividing line between the economic and monetary policies is not an easy task ${ }^{42}$ and it would be difficult even to conceive of a Treaty change in order to clarify that division. The idea that, given the limited democratic legitimacy of the ECB and ESCB, the scope of their powers must be interpreted restrictively may seem a prima facie solid argument to safeguard the democratic foundations of the Union. Furthermore, this interpretation is meant to enable the ECB and ESCB to only pursue

\footnotetext{
${ }^{36}$ Protocol 4 of June 7, 2016, on the Statute of the European Central Bank and of the European System of Central Banks, 2016 O.J. (C 202) 230. See ECJ, Case C-11/00, Commission v. European Central Bank, Case, 2003 E.C.R. I-07147, para. 134. See generally JeAn-Victor Louis, L’Union européenne et SA MONNAIE - Commentaire J. Mégret, Bruxelles 173 (2009).

${ }^{37}$ The EU may exercise only soft coordinating powers in this field on the basis of Articles 2(3) and 5(1) TFEU.

${ }^{38}$ For an analysis of the reality of relations between European monetary authorities and policy makers, see René Smits, The European Central Bank's Independence and Its Relations with Economic Policy Makers, 31 FORDHAM INT'L L. REV. 1614,1624 (2007).

${ }^{39}$ See Judgment of May 5, 2020 at paras. 142-3, 161.

${ }^{40}$ See Judgment of May 5, 2020 at para. 232.

${ }^{41}$ See Lorenzo Bini Smaghi, The Judgment of the German Constitutional Court is Incomprehensible (May 15, 2020), LUISS School of European Political Economy (May 15, 2020), https://sep.luiss.it/sites/sep.luiss.it/files/The\%20Judgment\%20of \%20the\%20GCC\%20is\%20incomprehensible-LBS_0.pdf.

${ }^{42} \mathrm{See}$, amongst others, the opinion of a former deputy governor for monetary policy of the Bank of England, who predicts that bonds purchase programmes by central banks will be increasingly needed in the future. This would be due to a series of factors emerging nowadays, including the existence of forces not under monetary authorities' control that influence interest rates and the increase in liquidity demand. Therefore, he affirms that: "[t]he distinction between monetary and fiscal policy has become increasingly blurred. And the distributional consequences of monetary policy have become increasingly contentious." Charles Bean, Central Banking has Never Looked More Daunting, FinanCIAL Times, December 4, 2017.
} 
monetary policy objectives. Nonetheless, such a construction may have the paradoxical effect to put too rigid limits to the activity of the ESCB and the ECB and to hamper the efficiency of the monetary policy. Once economic policy effects have been identified ${ }^{43}$ the question will raise as to the tolerability of such effects. The choice between different policy options in the area of the economic policy should, of course, rest with the political Institutions. Yet, restricting the monetary mandate in the way defined by the BVerfG does not chime with the complexities of the real world, as it reflects an idea which is too simplistic with respect to the multifaceted interrelations between economic forces. ${ }^{44}$ The task of taking into consideration the economic policy effects of monetary policy measures falls within the monetary policy mandate, under Article 127 TFEU and, as regards States of the Eurozone, their Economic policy competences are limited accordingly, by virtue of Article 5(1), second indent TFEU. ${ }^{45}$ In addition, entering into the complex assessment of the impact of monetary policy measures on, inter alia, unemployment or public debt management (because of the effects of interest rates) is a risky exercise for jurisdictions. Therefore, a deferential standard of revision should be adopted: only contradictory or blatantly irrational decisions, or decisions that manifestly run counter the economic policy objectives of the $\mathrm{EU}^{46}$ could be struck down by judges. The intensity of judicial control should be limited and in any case judges should never substitute their reasoning with that of technical bodies. This would not just entail the risk of going wrong and being criticized by specialists, but also, in the end, to impinge on central bankers' independence. ${ }^{47}$

\section{The Duty of Loyal Cooperation and the Principle of Conferral}

We submit that the BVerfG has also failed to comply with the duty of loyal cooperation laid down in Article 4(3) TEU, in connection with the aforementioned provisions and with the principle of conferral. The latter lies at the heart of the legal reasoning of the Court sitting in Karlsruhe, which

\footnotetext{
${ }^{43}$ These effects have been carefully analysed in many documents of the ESCB, although they are not referred to in the decision setting up the PSPP. See Weiss judgment at paras. 36-37, 40 and 74. For a recent analysis of the economic impact of the PSPP carried out by the Governing Council, see Account of the monetary policy meeting of the Governing Council of the European Central Bank held in Frankfurt am Main on Wednesday and Thursday, 3-4 June 2020, June 25, 2020, https:// www.ecb.europa.eu/press/accounts/2020/html/ecb.mg200625 fd97330d5f.en.html.

${ }^{44}$ See Lorenzo Bini Smaghi, supra note 41 , at 8.

${ }^{45}$ According to Article 5(1), second indent TFEU, "special provisions" apply to Member States whose currency is the euro as regards competences in the field of economic policy. The most immediate and natural reference seems to be to Chapter IV of Title VIII of Part Three of the TFEU (entitled "Provisions specific to Member States whose currency is the euro"), including legal bases that expand EU competences in economic policy. However, "special provisions" should also be intended as referring to other Treaty articles implying increased EU competences in economic policy for the functioning of the Eurozone, like those conferring powers on European monetary authorities, e.g. Article 127(1) TFEU, which envisage an incidence of monetary operations on economic policy. This reading of the competences framework is also confirmed by practice. See for more details Roberto Cisotta, Financial stability and the reconstruction of the EU legal order in the aftermath of the crisis, in FROM

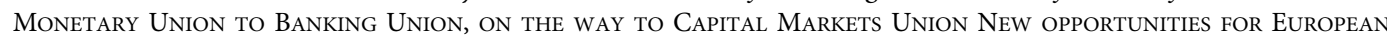
INTEGRATION 283, 284 (European Central Bank ed., 2015).

${ }^{46}$ Treaty on the Functioning of the European Union, art. 127(1) (1958) (establishing that, "[w]ithout prejudice to the objective of price stability, the ESCB shall support the general economic policies in the Union with a view to contributing to the achievement of the objectives of the Union as laid down in Article 3 of the Treaty on European Union.").

${ }^{47}$ For a thorough discussion of this point, see Matthias Goldmann, Adjudicating Economics? Central Bank Independence and the Appropriate Standard of Judicial Review, 15 GERMAN L.J. 265 (2014); Stefanie Egidy, Judicial Review of Central Bank Action: Can Europe Learn from the United States?, in BUILDING BRIDGES: CENTRAL BANKING LAW IN AN INTERCONNECTED WORLD 53 (2019); Peter M. Huber, The ECB under Scrutiny of the Bundesverfassungsgericht, in BuILDING BRIDGES: CENTRAL BANKING LAW IN AN INTERCONNECTED WORLD 28 (2019); Lars Bay Larsen, Legal Bridges over Troubled Waters? Standard of Review of ECB Decisions by EU Courts, in BuILding Bridges: Central BANKIng LAW IN AN INTERCONNECTED World 47 (2019); Chiara Zilioli, The Standard of Review of Central Banks Decision: an Introduction, in BuILDING BRIDGES: CENTRAL BANKING LAW IN AN INTERCONNECTED WORLD 23 (2019).
} 
demands to retain a form of control over the exercise of the competences conferred upon the Union and its Institutions, namely the Court of justice, by way of a scrutiny on the way it applies the principle of proportionality. ${ }^{48}$

It is true that the principle of conferral is functional to the preservation of Member States' sovereignty. Indeed, under Article 5(2) TEU, the Union can act "only within the limits of the competences conferred upon it" and Member States retain the competences not conferred on the EU. Nonetheless, the first sentence of Article 5(1) specifies that the action of the Union shall be carried out "to attain the objectives set out" in the founding Treaties. In our opinion, the meaning of this expression must be read in the light of the autonomy of the EU legal order and of the room for manoeuvre that the EU Institutions were given when performing their tasks. Here the duty of loyal cooperation comes into play by obliging Member States to assist the Union and its Institutions when carrying out their duties. ${ }^{49}$

The German Constitutional Court is of course aware of the obligation stemming from Article 4(3) TEU. The Court sitting in Karlsruhe has to some extent endeavoured to comply with it. Indeed, on the one hand, the BVerfG referred to the CJEU in the framework of Article 267 TFEU and, on the other hand, it placed on the interested national authorities the obligation to eliminate the flaws of the PSPP..$^{0}$ Yet, for the German constitutional judges a limit is reached where the Union competences are exercised in the practice in a way that circumvents the procedure for a Treaty amendment. ${ }^{51}$ In light of this statement, it is crucial to identify what for a constitutional court is the acceptable degree of tolerance of the concrete exercise of Court of Justice's competence. ${ }^{52}$ At the same time, such an attitude should be weighed against the obligations stemming from the EU membership.

The BVerfG is also conscious of the fact that the activation of its ultra vires review is an act of rupture from the point of view of the EU. Indeed, it is a deliberate breach of the general rule which the Karlsruhe Court declares to respect, whereby it is for the CJEU only to assess the legality of an EU law act. ${ }^{33}$ In the words of the BVerfG, "the constitutional perspective might

\footnotetext{
${ }^{48}$ See Judgment of May 5, 2020 at paras. 49, 123(bb), 127, 134(a), 136, 142-3, 156, 158, 160. In para. 110(b), the German Constitutional Court clarifies that in order to activate the ultra vires review, the violation of the principle of conferral must be sufficiently qualified, i.e. the EU should exercise a competence that is not conferred upon it, thus eluding the Treaty amendment procedure. This would cut off the national legislature, which should be involved in such procedure. See, on the use of the principle of proportionality, Giuseppe Tesauro \& Patrizia De Pasquale, La BCE e la Corte di Giustizia sul Banco degli Accusati del Tribunale Costituzionale Tedesco, Il Diritto Dell'Unione europea: Osservatorio europeo, May 11, 2020, http://images. dirittounioneeuropea.eu/f/sentenze/documento_DWGpI_DUE.pdf; Sara Poli, The Ruling of the German Federal Court of 5 May 2020: a Crisis within the Crisis or a Window of Opportunity for Further Reforms in the EU?, EUROJUs, June 11, 2020, http://rivista.eurojus.it/the-german-federal-court-and-its-first-ultra-vires-review-a-critique-and-a-preliminary-assessmentof-its-consequences/.

${ }^{49}$ The origin of the principle of loyal cooperation has to be traced back to the duty to act in bona fide means under international law, in particular in the performance and implementation of Treaties, as enshrined in Article 26 of the Vienna Convention of the Law of the Treaties. See V. Constantinesco, L'Article 5 CEE : De la bonne foi à la loyauté communautaire, in Du Droit international Au Droit de L'intégration: Liber AMicorum Pierre Pescatore 97, 108-109 (F. Capotorti \& P. Pescatore eds., 1987) (stating that the essence of loyal cooperation is, at the end, the expression of the principle of "non-contradiction" in respect of the obligations assumed by states under international law, in particular in the context of an international organization). See also Eleftheria Neframi, La force integrative du statut du de l'État membre dans la fonction juridictionnelle, in LE STATUT D'ETAT MEMBre DE L'UNION EUROPÉENNE: QUATORZIËMES JOURNÉES JEAN Monnet 333, 334 (Laurence Potvin-Solis ed., 2018).

${ }^{50}$ Therefore, it can also be discussed whether or not it is appropriate to start an infringement procedure before the conclusion of the whole question within the German legal order (and with the help, probably of the EU Institutions). See supra Sections B \& C.

${ }^{51}$ See Judgment of May 5, 2020 at para. 111.

${ }^{52}$ Issues related to the desirability of more diplomatic approaches and languages of the involved Courts will not be addressed here.

${ }^{53}$ See Judgment of May 5, 2020 at para. 111.
} 
not perfectly match the perspective of EU law given that, even under the Lisbon Treaty, the Member States remain the 'Masters of the Treaties' and the EU has not evolved into a federal state." ${ }^{54}$ In other terms, the German Constitutional Court is attempting to derive its power to carry out, although 'with restraint', ${ }^{55}$ its ultra vires review from the inherent structure and logic of the EU legal order itself, as lastly shaped by the Lisbon Treaty. Yet, in the EU system it is not possible to implicitly derive a judicial power to review EU acts: indeed, the EU legal order is an autonomous one and its system of judicial protection is one of the essential features of this autonomy ${ }^{56}$ which is protected by the Court of Justice. Therefore, in this respect the construction of the Judgment of 5 May amounts to a violation of Article 4(3) TEU, in addition to and in combination with the mentioned provisions regarding the exercise of jurisdiction by the CJEU.

National Courts should accept the logic of the preliminary ruling whereby there is no residual room for adjudication by them on the legal issues decided by the CJEU, including the interpretation of Article 123 TFEU. This stems from the very essence of the principle of conferral, whereby Member States do not simply delegate powers under the understanding that they might revoke the delegation when they disagree with the way the EU Institutions exercise such powers. Under the principle of conferral, in connection with the duty of loyal cooperation, it is forbidden that national Courts scrutinize the exercise of the powers conferred to the EU Institutions. ${ }^{57}$ Those authorities should not, in particular, decide at any time that the system of judicial review does not satisfy the requirements flowing from their national law since this would amount to a revocation of the powers conferred on the EU institutions. Such a revocation is only possible through a Treaty change; ultimately, should the Member State concerned not to be satisfied of the conditions of its EU membership, the decision should be made to withdraw from the Union. ${ }^{58}$ So long as this does not happen, national authorities of EU members cannot exercise the powers conferred to the Union; the EU system should be left free to function according to its internal rules and this clearly applies to all the Institutions involved, including the ECB. ${ }^{59}$ Indeed, Member States' obligation to abstain from interfering with the exercise of powers conferred on the EU is intended to safeguard the functioning of the Union. In a community of law, infringing such an obligation would go against the principle of equality between sovereign Members of the organization that accepted, each one of them on the basis of a democratic choice, to transfer their powers to the EU.

Setting aside a preliminary ruling on the validity of an EU act on the basis of a domestic understanding $^{60}$ of the proportionality principle is irreconcilable with the basic principles of the judicial

\footnotetext{
${ }^{54} J$ udgment of May 5, 2020 at para. 111 (emphasis added).

${ }^{55}$ See Judgment of May 5, 2020 at para. 112.

${ }^{56}$ See Opinion 2/13. See also Section D.I.

${ }^{57}$ The power to carry out some kind of ex-post review on EU law acts, including the judgments of the CJEU, is vindicated by various Constitutional Courts around Europe. Such powers should nevertheless be viewed as stemming from national constitutional sources (with a variety of reconstructions and procedural differences). See Enzo Cannizzaro, EU Law and National Constitution: a Pluralist Constitution for a Pluralist Legal Order?, 1 F.I.D.E XX Congress London 243 (2002). Yet, the activation of those national mechanisms can be regarded as a breach in the EU context.

${ }^{58}$ See R. Daniel Kelemen et al., National Courts Cannot Override CJEU Judgments, VerfBlog (May 26, 2020), https:// verfassungsblog.de/national-courts-cannot-override-cjeu-judgments/. Before taking an initiative that could bring the situation to a point of no return, a Member State may choose to take any appropriate action within its domestic legal order (like legislative and/or constitutional reforms) or even in the EU context.

${ }^{59}$ According to the statement of Marc Wan der Woude, President of the General Court, June 6 2020, https:// g8fip1kplyr33r3krz5b97d1-wpengine.netdna-ssl.com/wp-content/uploads/2020/06/VDV-EN.pdf, "it must be noted that the [5 May decision of the BVerfG] does not concern the delimitation of the respective competences of the EU and the relevant Member State, but constitutes a direct interference in the functioning of the European legal order."

${ }^{60}$ The CJEU is better placed than domestic courts to adjudicate on the validity of an EU Law act, see Gaston Schul Douaneexpediteur BV, Case C-461/03.
} 
protection system established by the EU Treaties. ${ }^{61}$ It is a truism to say that should each national Constitutional or Supreme Court carry out such a review, the preliminary ruling mechanism and the whole EU legal system would no longer work. It is submitted that in an effort to comply with art. 4(3) TEU, the BVerfG could have made a new reference to the CJEU, under art. 267 TFEU, after the Weiss judgment. The referring court could have asked new questions on points of EU law that were not asked (and therefore not answered) by CJEU in the first preliminary ruling: for example, it could have inquired about the legal value of the formal and informal documents of the ESCB and ECB analysing the economic impact of the PSPP for the interpretation of the decision establishing the Programme. ${ }^{62}$

\section{E. Final Remarks}

After an examination of the objective breaches of EU law that may be associated with the judgment of May 5, 2020, it was emphasised that it would be possible to open an infringement procedure against Germany from a legal point of view. Yet, it is now up to the state organs (in particular the Bundesbank, ${ }^{63}$ which is also the major shareholder of the ECB) to take any appropriate step to reconcile the activity of the EU with the requirements emerging by the Grundgesetz, as interpreted by the Karlsruhe Court. ${ }^{64}$ It is possible that in the near future the President of the Bundesbank will be invited by the Bundestag to give an account on how the ECB Governing Council deliberations with respect to the PSPP were made, without breaching the confidentiality rules of the mentioned body. ${ }^{65}$

It would be desirable that a solution to the conundrum due to the first verdict by the BVerfG holding an EU act to be ultra vires was found within the domestic legal order. Indeed, should the Bundesbank be in the position to continue to participate in the PSPP Programme, it would probably not be in the common interest to open (or to continue) an infringement procedure.

\footnotetext{
${ }^{61}$ The Court of Justice has already ruled in the Melki and Abdeli judgment that it would be impermissible that a question of compatibility of a national law with EU law could be solved by a national constitutional court with a binding effect on all national lower courts (which were in the circumstances of the case also prevented from referring to the CJEU after the ruling of the national constitutional court had been delivered). See ECJ, Joined Cases C-188, 189/10, Melki and Abdeli, ECLI:EU: C:2010:363 (June 22, 2010), http://curia.europa.eu/juris/document/document.jsf?text=\&docid=80749\&pageIndex=0\& doclang $=\mathrm{EN} \&$ mode $=1 \mathrm{st} \& \operatorname{dir}=\& \mathrm{xcc}=$ first $\&$ part $=1 \& \mathrm{cid}=6334723$. The CJEU has already affirmed that Member States have to set up, also with active behaviours under their obligations stemming from the founding Treaties, the conditions for the European Institutions to operate and let them do it autonomously. See Case 230-81, Luxembourg v. European Parliament, 1983 E.C.R. 255, paras. 37-38; Joined Cases 358/85 \& 51/86, France v. European Parliament, 1988 E.C.R. 4821, paras. $34-36$. Interferences in the functioning and independence of the EU must be demonstrated, as the European Institutions cannot otherwise-being subjected to the duty of loyal cooperation in their turn-oppose a refusal to the legitimate requests of cooperation by Member States. See Case C-2/88, Imm., Zwartveld et al., 1988 E.C.R. I-3365, paras. 17-21. The duty of loyal cooperation is binding for all national authorities, including the Judiciary, see Case 14/83, Von Colson and Kamann v. Land Nordrhein-Westfalen, 1984 E.C.R. 1891, para 26; Case 80/86, Criminal proceedings against Kolpinghuis Nijmegen BV, 1987 E.C.R. 3969, para. 12.

${ }^{62}$ See supra note 43.

${ }^{63}$ See Jens Weidmann, President of the Bundesbank, Statement on the Judgement of the Federal Constitutional Court, May 5, 2020, https:/www.bundesbank.de/en/press/press-releases/statement-by-bundesbank-president-jens-weidmann-on-thejudgement-of-the-federal-constitutional-court-bundesverfassungsgericht-832414. The Governing Council of the ECB is reported to be called to give its justification on the proportionality of the PSPP; yet, it is not clear from this press release whether the Bundesbank would take the initiative for the adoption of an act amending the decisions challenged before the BVerfG or a newly adopted decision, or for other possible solutions.

${ }^{64}$ The BVerfG could not have directly imposed anything on EU Institutions. See Judgment of May 5, 2020 at paras. 230-33.

${ }^{65} \mathrm{See}$ 'The trough is likely to be behind us now', Interview with Jens Weidmann, Frankfurter AllgEmEINE SonNTAGSZEITUNG, June 21, 2020, https:/www.bundesbank.de/en/press/interviews/-the-trough-is-likely-to-be-behind-usnow-835032. https://www.bundesbank.de/en/press/interviews/-the-trough-is-likely-to-be-behind-us-now-835032. https:// www.bundesbank.de/en/press/interviews/-the-trough-is-likely-to-be-behind-us-now-835032
} 
It is not the first time that a national constitutional court does not share the view of the CJEU on fundamental principles of the EU edifice such as that of the primacy of EU law. In the past, it has taken some time to reconcile conflicting views of the domestic courts and the CJEU. In the present circumstances, in the absence of appropriate corrective action on the part of the German politial institutions and of the Bundesbank, an existential crisis for the euro area, going beyond a divergence in the jurisprudence of the two involved Courts, may follow. The judgment of May 5, 2020 remains a prominent judicial pronouncement that will put some constraints on the action of the EU Institutions, including the ECB. It might also create the conditions for new conflicts between the domestic constitutional courts and the CJEU.

Cite this article: Poli S, Cisotta R (2020). The German Federal Constitutional Court's Exercise of Ultra Vires Review and the Possibility to Open an Infringement Action for the Commission. German Law Journal 21, 1078-1089. https://doi.org/10.1017/ glj.2020.57 